\title{
Do both habitat and species diversity provide cultural ecosystem services? A trial using geo-tagged photos
}

\author{
Takeshi Osawa', Yusuke Ueno ${ }^{2,4}$, Takaaki Nishida ${ }^{3,5}$, Jun Nishihiro ${ }^{4,6}$ \\ I Graduate School of Urban Environmental Sciences, Tokyo Metropolitan University. Minami-Osawa 1-1, \\ Hachiouji, Tokyo, 192-0397, Japan 2 Ishikawa Prefectural University, 1-308, Suematsu, Nonoichi-shi, Ishi- \\ kawa-ken, 921-8836, Japan 3 Mitsubishi UFJ Research and Consulting Co., 5-11-2, Toranomon, Minato-ku, \\ Tokyo 105-8501, Japan 4 Faculty of Science, Toho University, 2-2-1 Miyama, Funabashi-shi, Chiba 274- \\ 8510, Japan 5 Kyoto Sangyo University, Motoyama, Kamigamo, Kita-ku, Kyoto, 603-8555, Japan 6 Center \\ for Environmental Biology and Ecosystem Studies, National Institute for Environmental Studies, 16-2 Onoga- \\ wa, Tsukuba, Ibaraki, 305-8506, Japan
}

Corresponding author: Takeshi Osawa (arosawa@gmail.com)

Academic editor: Yu-Pin Lin | Received 14 May 2019 | Accepted 9 March 2020 | Published 18 March 2020

http://zoobank.org/9A91F516-1C39-4E4B-B645-EA4C9313B069

Citation: Osawa T, Ueno Y, Nishida T, Nishihiro J (2020) Do both habitat and species diversity provide cultural ecosystem services? A trial using geo-tagged photos. Nature Conservation 38: 61-77. https://doi.org/10.3897/ natureconservation. 38.36166

\begin{abstract}
Conservation for both biodiversity and ecosystem services are an important issue worldwide. However, knowledge of their relationship remains limited. As habitat structure is strongly related to regional biodiversity, we studied cultural ecosystem services by using habitat structure as a proxy for biodiversity. Specifically, we used human preference, assessed by using photos with location information (i.e. geo-tagged digital pictures) as an index of a cultural ecosystem service. We conducted nature walks in semi-natural environments for cognitively-impaired students from a local special school and studied the photos they took during the walks. We analysed the habitat preferences inferred from the photo locations and the composition of the photoswhether they were close-up, scenic or landscape views. The results showed that levels of human preference and biodiversity, indicated by habitat structure, had a positive relationship. During spring to autumn, when levels of biological activity are higher, people tended to show more preference in close-up views (i.e. the subject of the photo was the species itself). In winter, they tended to be interested in scenic views that were not strongly influenced by species diversity. Additionally, photos taken in areas with threatened species almost always included close-up views, although not of the threatened species themselves. Areas with high species diversity therefore appeared to be more appealing to the participants. These results suggest that habitat diversity could not only contribute to biodiversity, but also provide cultural ecosystem services. Habitat conservation for seminatural environments could be synergised for both biodiversity conservation and general human well-being.
\end{abstract}

Copyright Takeshi Osawa et al. This is an open access article distributed under the terms of the Creative Commons Attribution License (CC BY 4.0), which permits unrestricted use, distribution, and reproduction in any medium, provided the original author and source are credited. 


\section{Keywords}

Cultural services, habitat type, human interest, human-biodiversity relationships, non-material benefits, phenology

\section{Introduction}

Ecosystem services which provide benefits to people from ecosystems are important to human societies and to economies (Millennium Ecosystem Assessment 2005; Mace et al. 2012). Fostering a broad range of ecosystem services has become a dominant environmental paradigm that has opened up important conservation opportunities around the world (de Groot et al. 2010; Plieninger et al. 2013; Castro et al. 2014). However, as is the case with biodiversity, ecosystem services are declining worldwide, spurring scientists and policy-makers to act together to identify effective policy solutions (Mace et al. 2012; Balvanera et al. 2014; Boerema et al. 2017). Identifying the impacts of biodiversity and detecting ecosystem services on human well-being and making appropriate conservation efforts are crucial to addressing social requirements.

Motivations for the conservation of the natural environment differ (Mace et al. 2012; Mori 2017). For example, biologists and bird watchers may be primarily interested in biodiversity itself, whereas others may be more concerned with beautiful scenery or clean air (i.e. non-biological components) (Cumming and Maciejewski 2017). Realistically, setting conservation goals amongst such varied stakeholders is difficult because of their diverse motivations and/or preferences (Martin-López et al. 2012; Van Berkel and Verburg 2014; Garrido et al. 2017). This difficulty acts as a barrier to promoting biodiversity conservation activities by society as a whole, that is, activities that internalise the social-ecological systems. Approaches that could integrate such diverse motivations should be a central theme in practical conservation planning. In this context, illustrating the key role of biodiversity as a provider of general human well-being through ecosystem services is a good solution to mainstream the concept of biodiversity conservation. Studies evaluating biodiversity, including functional diversity and ecosystem services, have been extensively conducted and discussed in the past decade (Tilman et al. 2006; Mace et al. 2012; Cadotte 2013; Doi et al. 2013; Balvanera et al. 2014; Mori 2017; Schwarz et al. 2017; Thompson et al. 2018). However, an understanding of the relationships between biodiversity and ecosystem services remains limited (Cardinale et al. 2012; Balvanera et al. 2014; Boerema et al. 2017; Schwarz et al. 2017).

Physical structures (i.e. habitat structures) are strongly related to regional biodiversity and/or ecosystem functions and are relatively easy to observe; thus, they are often used as a proxy to evaluate biodiversity (Osawa et al. 2010a, b; Marull et al. 2015). If we could also detect ecosystem services derived from habitat structures that are likely to produce high biodiversity and/or ecosystem functions, it would be useful in integrating motivations for conservation. In this study, we tried to identify human well-being that is derived from habitats and their diversity and that relate to regional biodiversity and/ 
or ecosystem functions, focusing on cultural services, defined as non-material benefits derived from human-ecosystem relationships (Chan et al. 2011, 2012a). Non-material services, including cultural services, do not exclude other functions or services; thus, identifying a cultural service (i.e. an additional value) could contribute to options for the future development of a target ecosystem (Chan et al. 2012b; Van Berkel and Verburg 2014). However, these types of ecosystem services are difficult to evaluate because their value is non-economic (Chan et al. 2012a; Boerema et al. 2017; Schwarz et al. 2017; Gomes et al. 2018). To identify these services, we used human-interest photos tagged with location information (i.e. geo-tagged pictures), which have been previously suggested as potential indices of cultural services (Martínez Pastur et al. 2016; Yoshimura and Hiura 2017). Generally, people take a photo for objects in which they have a positive interest i.e. preferences. The Millennium Ecosystem Assessment (2005) categorised cultural services as mainly seven: spiritual and religious, recreation and ecotourism, aesthetic, inspirational, sense of place, cultural heritage and educational (Millennium Ecosystem Assessment 2005; Hernández-Morcillo et al. 2013) that almost of all categories would relate to human interests. Especially, recreation and ecotourism and sense of place are likely to relate directly with human interests i.e. preferences. Actually, previous studies indicated that revealed preference techniques have been useful in estimating the ecosystem service that is difficult to evaluate directly (Sherrouse et al. 2011; Casado-Arzuaga et al. 2014; Van Berkel and Verburg 2014).

In this study, we tried to assess the relationship between habitat structure and human interests i.e. their preferences using geo-tagged photos, with a focus on detecting ecosystem services derived from biodiversity-related components. A previous study indicated that people preferences are useful for assessing the demand side of the ecosystem services (Casado-Arzuaga et al. 2014). People demand is important for assessing a cultural service because cultural services are not solely a function or a one-way flow from natural ecosystems to people, but they are co-generated through the interaction of people and the environment (Casado-Arzuaga et al. 2014). We predicted that there would be positive relationships between the variety of habitat structures (as an index of biodiversity) and human interest i.e. preferences. Specifically, people do not prefer areas with a very simple habitat structure (i.e. those with low species diversity) because inherently human interests should be variety. Dallimer et al. (2012) indicated that the natural environment has generally been treated as uniform, such as green space, when testing non-material human well-being; thus, incorporating habitat structure could provide a new insight for this field. We also predicted that phenology would influence human interest, that is, there might be differences between seasons with high biological activity and those with low activity. Phenology also could cause habitat differences with time which could influence human interests. Thus, we predicted habitat diversity could contribute to both biodiversity and human well-being simultaneously with different mechanisms. This idea could expand our understanding of relationships between natural phenomena and non-material human well-being, so we tested these hypotheses in a semi-natural area. 


\section{Methods}

\section{Study area}

The study was conducted in the Asabata Yusuichi retarding pond, Shizuoka Prefecture, Japan $(35.02 \mathrm{~N}, 138.40 \mathrm{E}, 55$ ha; Fig. 1). This area is about a 30 -minute drive from Shizuoka Station, a central station in the Prefecture. The terrain of this area is flat; thus, it has a relatively high risk of flooding. In fact, the area experienced heavy rains in 1974 known as "Tanabata gouu" and heavy flooding occurred. After this disaster, the Asabata Yusuichi retarding pond was constructed to reduce the risk of future flooding.

A nature restoration project managed by local governments has been continuing in the area since 2008 because it contains not only the pond but also several other types of habitats, such as wetland, grassland and secondary forest, containing several threatened species (Shizuoka Prefecture, Shizuoka City Council on Asabata Yusuichi 2008). After the project was established, resident groups were created to discuss the conservation, sustainable use and applicable management of natural resources, in collaboration with a wide range of stakeholders (http://asabata.org/, in Japanese, accessed on 20 Jan 2020). One of the resident groups aims to collaborate with a special school to support student studies and their independent living (http://asabata.org/shien/\%E3\%83\%99 \%Е3\%83\%BC\%E3\%83\%86\%E3\%83\%AB\%E9\%BA\%BB\%E6\%A9\%9F\%E9\%83 \%A8\%Е4\%BC\%9A\%Е3\%81\%AE\%E5\%8F\%96\%Е3\%82\%8A\%Е7\%B5\%84\%Е3 $\% 81 \% \mathrm{BF} /$, in Japanese, accessed on 20 Jan 2020).

\section{Data collection}

We conducted nature walks in a semi-natural environment for participants and cognitively-impaired students from a local special school. We used photos taken by the participants during the walk events to evaluate human interest. Before conducting the analysis, we obtained permission and agreements with teachers and legal guardians for using these photos. We collected photos taken by the cognitively-impaired students who were unlikely to have any bias for ecosystem services. Thus, we predicted that the interests of non-impaired people would probably be influenced by lectures at nature walk events. For example, if an event lecturer is familiar with birds, then participants may tend to focus on birds. Alternatively, non-impaired participants might read brochures or reports published by the nature restoration project before the event and may focus on the threatened species in this area. Cognitively-impaired students would be unlikely to be biased. The special school is located near Asabata Yusuichi (Fig. 1) and collaborates with the nature restoration project, as described above, so the students often visit the area. Students are from class grades ranging from primary to high school (with ages about 7-18 years). We conducted a number of nature walks with students from 2015 to 2017 and collected photos from seven of these walks. During 

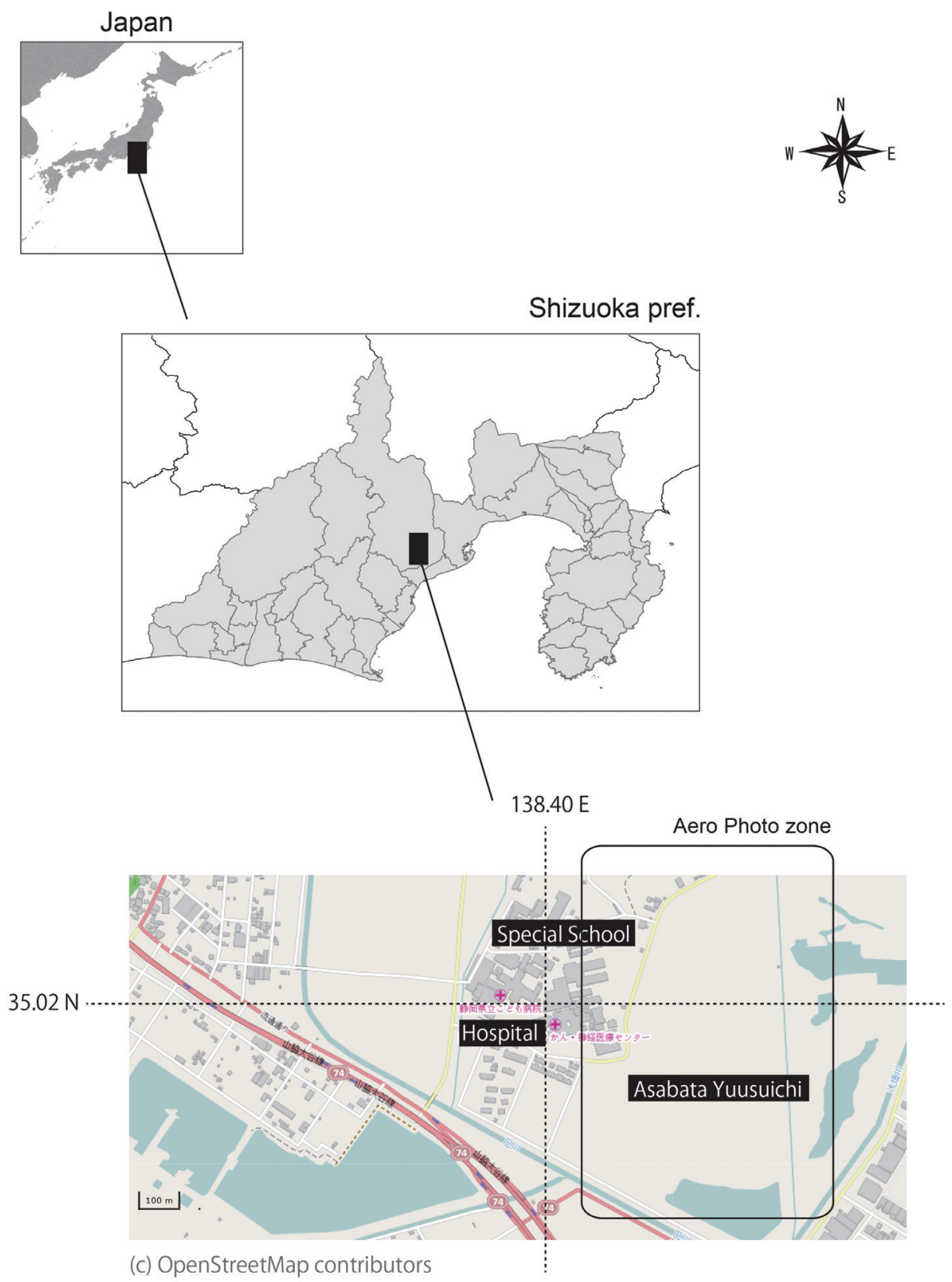

Figure I. Study area and some land marls in this study. We conducted the study in the part of Asabana Yusuichi.

the walks, students took photos of areas or things that interested them using digital cameras with geo-tagging capability (Ricoh WG-4). We did not use photos without attached geo-tags for this analysis. 


\section{Definition of picture composition}

We defined three types of picture compositions: close-up, scenery and landscape. If the subject in a photo was a single species or more than one species close enough to touch another, it was classified as a close-up view. If the subject was scenery that could be reached easily on foot, such as a grassland or a full view of a tree or stand, it was classified as a scenic view. If the subject was a landscape that could not be reached easily on foot, such as a mountain, it was classified as a landscape view. Typical pictures from each view are shown in Suppl. material 1: Fig. S1. Close-up views might be the most influenced by biological activity because people can define the target species, colour and shapes, while both scenic and landscape views would be less so, since wide-angle compositions tend to include non-biological objects. Before categorising the photos, we excluded some pictures that obviously overlapped with respect to objects and temporally adjacent time stamps.

\section{Land cover, habitat classification and field survey}

We used an aerial photograph taken in December 2016 to map the current land cover (Fig. 2a), which we classified as bare ground, forest, grassland, open water or paddy field according to our interpretation of the aerial photographs and ground-truth fieldwork. We used the land-cover types as an index of habitat and diversity. To create the land-cover map, we used GIS polygon data based on the photographs and conducted ground-truth fieldwork to evaluate the accuracy of the classifications. In this area, people can access all land-cover types, even the forest, because impenetrable vegetation is rarely present. We also developed GIS line data for the walking path. We divided Asabata Yusuichi into 30-m-square cells and assigned each grid to a category according to its dominant land cover class (Fig. 2b). We also categorised the cells according to whether they did or did not contain a walking path (Fig. 2c). We used these cells as analysis units to accommodate errors in the latitude/longitude coordinate values in the photograph metadata. We overlaid the photo location information and the land-cover map, assigned a dominant land-cover type to each photo location and noted whether or not the grid contained a walking path.

We also conducted a field survey from 2015 to 2017 to find and identify threatened plant species in the national Red List (http://www.env.go.jp/press/103881.html, in Japanese, accessed on 20 Jan 2020) and the prefectural Red Data Book (http://www. pref.shizuoka.jp/kankyou/ka-070/wild/red_replace.html, in Japanese, accessed on 20 Jan 2020). If we found a threatened species, we photographed it with the same camera type as used by the study participants to obtain location information. We defined each cell that contained one or more threatened species as an important habitat area (Fig. 2d). To avoid any potential intrusion by plant collectors, we do not show detailed location information for the threatened plants. 
( a ) Aerial photograph in 2016

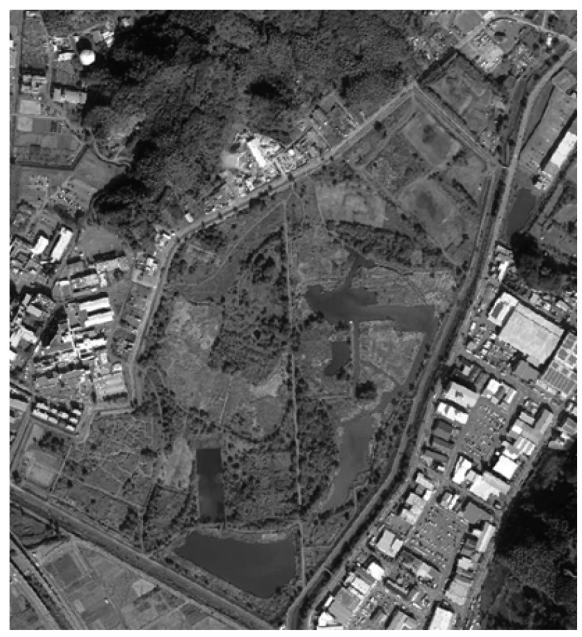

(c ) Map with points of shooting picture

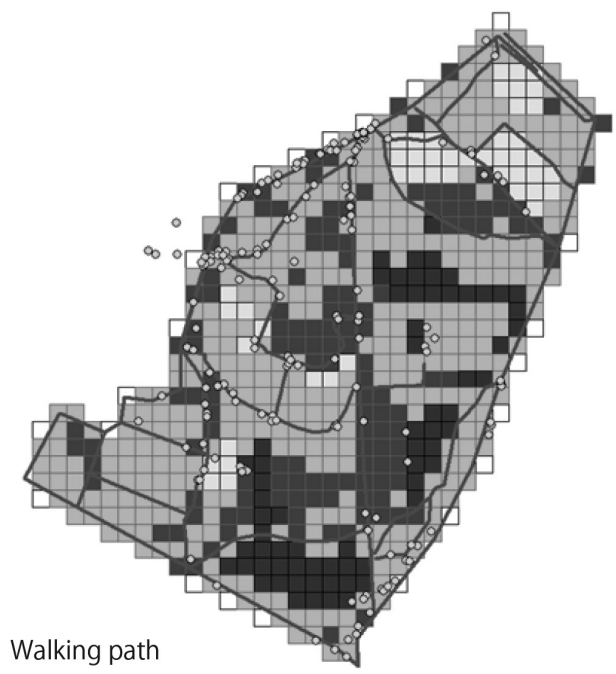

( b ) 30-m resolution land cover map

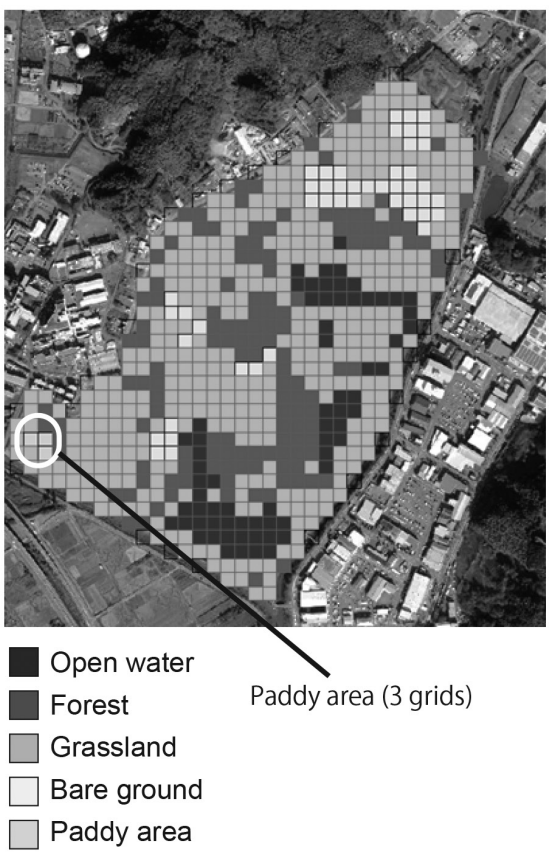

(d ) 30-m grids with threaten plants

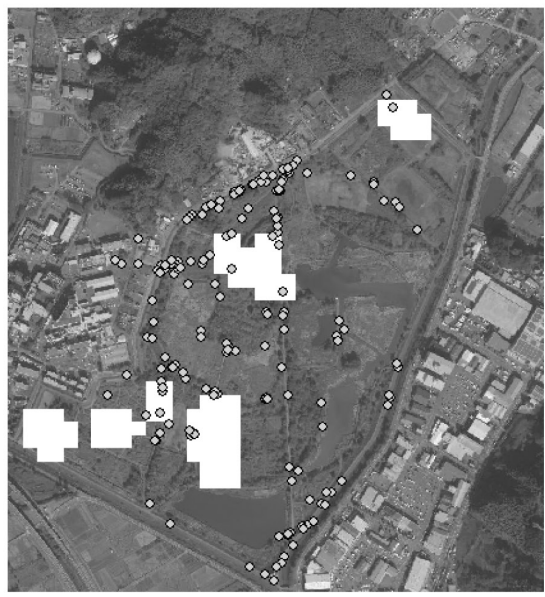

Points of shooting picthre

Figure 2. Aeriai photograph, land cover mesh map and location of shooting photos in the study area. Mesh size is $30 \mathrm{~m}$ square. 


\section{Species diversity}

We conducted a field survey, a literature search and a public hearing to evaluate species diversity in each land-cover type. We focused on plants, birds, butterflies and dragonflies, which are generally well-known taxa in Japan. We collected data on fauna and flora and their habitat requirements of each species from published sources (Takagawa et al. 2011; Ozono et al. 2012) and web resources (http://www.insects.jp, in Japanese, accessed on 20 Jan 2020). If a species had two or more major habitats, we recorded them all. Therefore, the total number of habitats and the total number of species are not equal in some cases. All the species and their required habitats are shown in Suppl. material 3: Tables S1-S4.

\section{Analysis}

We tested each photographer's preference for land-cover type (i.e. land cover) with Fisher's test in the following manner. The ratio of the number of photos of a particular land cover to the total number of photos taken was calculated for each land cover. This ratio was compared with the ratio of the total number of cells containing the land cover to the total number of all cells. A land cover was deemed to be "preferred" if the ratio of the number of photos was significantly larger than that of all cells; conversely, it was considered "not preferred" if the ratio of the number of photos was significantly smaller than that of all cells. We conducted this analysis for the entire area and for the walking-path cells only to account for the accessibility in the cells. We also compared differences in photo compositions from spring to autumn (March to October), which has high levels of biological activity, with those from winter (November to February), when biological activity is low. Additionally, we counted the preferred picture composition in cells that contained threatened plant species. All analyses were conducted using R software v. 3.1 .2 (https://www.r-project.org/, accessed on 20 Jan 2020).

\section{Results}

In total, 630 land cover cells were classified, of which 308 contained a walking path (Table 1). The ratio of cells containing a walking path did not bias any land-cover type ( $p>0.05$, Fisher's test on the ratio of the land cover types between all cells and those with a walking path), excluding open water ( $\mathrm{p}<0.001$, Fisher's test). This result was expected because there were no bridges over the water. Thus, the walking-path effects did not matter with respect to the land-cover type in each photo. Eighty cells (27 with a walking path) contained at least one threatened plant species. We analysed 232 photos (153 grassland, 58 forest, 15 bare ground and 6 open water): 126 were close-ups, 100 were scenic views and 6 were landscapes (Table 1). In terms of land cover preference, the student photographers tended not to prefer open water $(\mathrm{p}<0.001)$, but there were no land cover preference trends for the other land-cover types (Table 1). 
Table I. Number of $30 \mathrm{~m}$ land cover (LC) cells for each LC type and number of photos and type of composition. Numbers in parentheses indicate cells with a walking path or the number of photos taken in a cell with a walking path.

\begin{tabular}{lccccc}
\hline \multicolumn{1}{c}{ Land cover } & LC mesh number & Picture number & Close-up & Scenery & Landscape \\
\hline Grassland & $374(202)$ & $153(125)$ & $77(63)$ & $72(59)$ & $4(3)$ \\
Forest & $138(77)$ & $58(55)$ & $32(31)$ & $24(22)$ & $2(2)$ \\
Bare ground & $47(19)$ & $15(15)$ & $13(13)$ & $2(2)$ & $0(0)$ \\
Open water & $68(9)$ & $6^{* * *}\left(0^{*}\right)$ & $4^{*}(0)$ & $2^{* *}(0)$ & $0(0)$ \\
Paddy area & $3(1)$ & $0(0)$ & $0(0)$ & $0(0)$ & $0(0)$ \\
Total & $630(308)$ & $232(195)$ & $126(107)$ & $100(83)$ & $6(5)$ \\
Threatened plants & $80(27)$ & $17(10)$ & $11(6)$ & $6(4)$ & $0(0)$ \\
\hline
\end{tabular}

Fisher's test $*$ : $<<0.05, * * \mathrm{p}<0.01, * * * \mathrm{p}<0.001$.

Table 2. Number of species and their primary habitats. Numbers in bold indicate dominant habitat for the species group. Bird habitat was divided into breeding and overwintering seasons.

\begin{tabular}{lccccc}
\hline \multicolumn{1}{c}{ Main habitat } & Plant & Bird (breeding) & Bird (overwinter) & Butterfly & Dragonfly \\
\hline Grassland & 344 & 51 & 74 & 15 & 1 \\
Forest & 25 & 80 & 61 & 10 & 24 \\
Wetland (paddy field) & 110 & 73 & 118 & 0 & 24 \\
Pond, bog (open water) & 24 & 52 & 102 & 0 & 38 \\
Other & 10 & 62 & 129 & 11 & 24 \\
Total number of species & 513 & 219 & 219 & 23 & 49 \\
\hline
\end{tabular}

Species number were derived from field survey, literature search, and public hearing. Habitat information were derived from published sources (Ozono et al. 2012; Takagawa et al. 2011) and web resources (http://www.insects.jp, in Japanese)

Table 3. Timing of the nature walks and number of total photos and each type of composition.

\begin{tabular}{ccccccc}
\hline \multicolumn{1}{c}{ Year } & Month & Season & Total & Close-up & Scenery & Landscape \\
\hline 2015 & May & Spring & 66 & 49 & 16 & 1 \\
& June & Summer & 44 & 35 & 8 & 1 \\
& September & Autumn & 36 & 28 & 8 & 0 \\
2016 & October & Autumn & 1 & 1 & 0 & 0 \\
2017 & December & Winter & 40 & 8 & 29 & 3 \\
& January & Winter & 37 & 4 & 32 & 1 \\
& April & Spring & 8 & 1 & 7 & 0 \\
& Total & & 232 & 126 & 100 & 6 \\
\hline
\end{tabular}

The numbers of plant, bird, butterfly and dragonfly species in each main habitat, which were derived from a field survey, a literature search and a public hearing, are shown in Table 2. The grassland was dominant for plants and butterflies. A pond/bog (open water) was the main habitat for dragonflies. The forest was the primary habitat for birds during the breeding season (spring-autumn), whereas a wetland (paddy field) was their main winter habitat.

Most of the photos taken from spring to autumn were close-ups, whereas almost every photo taken in winter was of scenery (Fig. 3, Table 3). Landscape views were rarely taken in either period. 


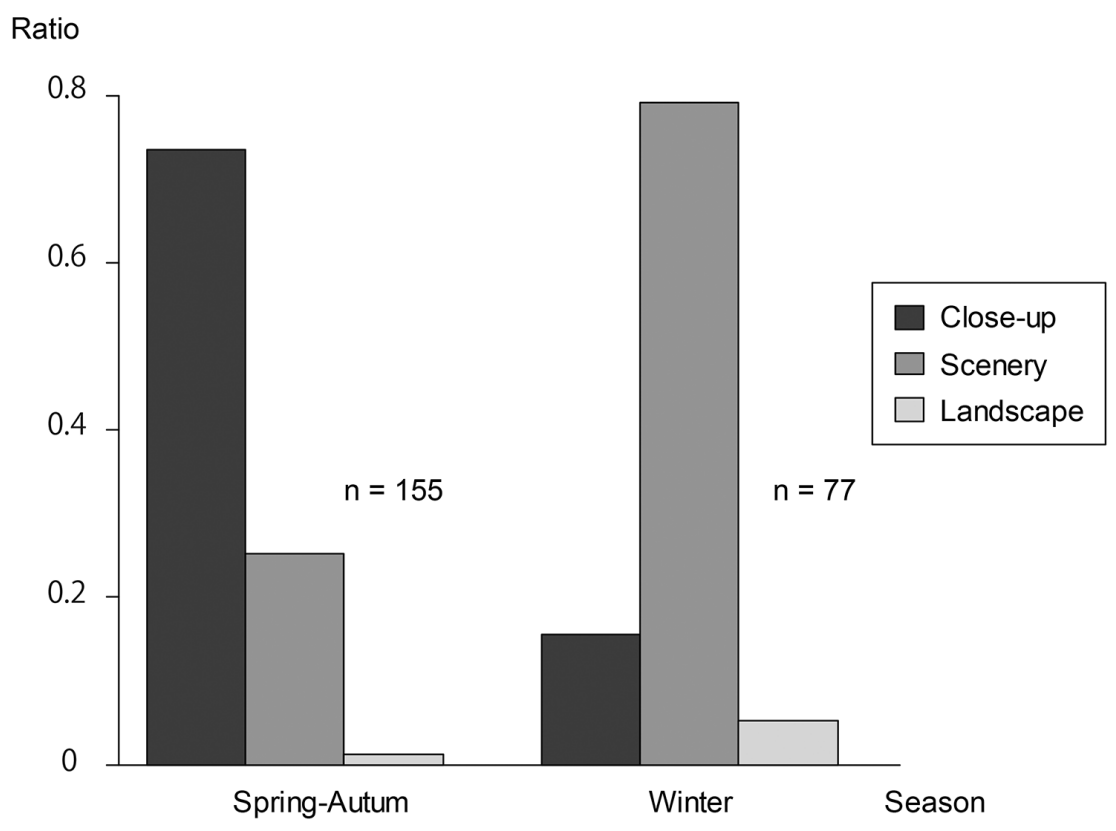

Figure 3. Barplot of the ratio of photo composition between spring to autumn and winter seasons.

Table 4. Composition of photos taken in cells that contained identified threatened plant species. Numbers in parentheses indicate cells with a walking path.

\begin{tabular}{lcccc}
\hline \multicolumn{1}{c}{ Seasons } & Total number & Close-up & Scenery & Landscape \\
\hline Spring, Summer and Autumn & $12(7)$ & $11(6)$ & $1(1)$ & $0(0)$ \\
Winter & $5(3)$ & $0(0)$ & $5(3)$ & $0(0)$ \\
\hline
\end{tabular}

We found 14 threatened plants in the study area (Suppl. material 3: Table S5). The composition of pictures taken in the cells containing threatened plants showed a clear trend. In spring to autumn, 11 of 12 photos were close-ups, whereas in winter, all five pictures were of scenery (Table 4). The subjects of the close-up photos were different in each picture (plants: Pueraria lobata, Mallotus japonicus, Calystegia japonica, Solidago altissima, Triadica sebifera and Dioscorea japonica; insects: Orthetrum albistylum and Acrida cinere; amphibian: Rana rugosa). There were, however, no close-up photos of threatened plants (Suppl. material 3: Table S6).

\section{Discussion}

We analysed the preferences of students who participated in taking photos of landcover types using geo-tagged photos as an index of a cultural ecosystem service. Results showed that land cover (i.e. habitat) structure, which could contribute to biodiversity, 
could also attract more people preferences i.e. indicator of cultural services. Additionally, our results suggested that natural or semi-natural land-cover types could provide cultural ecosystem services that cannot be provided by artificial land-cover types. These results suggest that the conservation of habitat diversity could contribute not only to regional biodiversity itself but also to human well-being as an additional value.

We classified five land cover types (grassland, forest, bare ground, open water and paddy field) to use as indices of habitat type. Each habitat type, except for bare ground, was used as the primary habitat for at least some of the flora and fauna surveyed in the area. These results indicate that habitat diversity could directly contribute to regional species diversity in the study area. In other words, if the number of habitat types decreased or the habitats degraded, species diversity could also decline. Our study area contains several habitat types as well as a mosaic structure of semi-natural habitats. Although we did not evaluate it in this study, this type of mosaic habitat structure could contribute to biodiversity and ecosystem functions (Tscharntke et al. 2005; Yoshioka et al. 2017). Thus, the land cover of Asabata Yusuichi has currently contributed to regional biodiversity and ecosystem functions, at least from a biological perspective.

People's preferences varied amongst the habitat types such that no single habitat, excluding open water, was notably more preferred over another. This result suggests that each habitat holds its own appeal. Thus, diverse habitat types, each having unique species components, may fulfil people's diverse subjective preferences. Our results suggest that each habitat could contribute its own species groups, so human interests and species diversity could be matched. Kasada et al. (2017) indicated that places with both high human interest and high biodiversity are valuable in maintaining human-biodiversity relationships (Kasada et al. 2017). An area that has diverse habitats and easy accessibility, such as Asabata Yusuichi, could contribute to both regional biodiversity and maintaining human-biodiversity relationships. If the overall habitat composition became simpler (i.e. the number of habitat types was reduced), the preferences in such habitats would be restricted to only people with preferences for those types. Therefore, we conclude that diverse habitats are an important resource for not only species diversity but also cultural ecosystem services.

We found clear seasonal differences in picture composition. During spring to autumn - a period with high biological activity - people tended to take close-up photos (i.e. of a particular species). Conversely, in winter, they tended to be preferred in scenic views, which were not strongly influenced by the species present. This trend was most notable in photos taken in the cells containing threatened plants. Of course, scenic and landscape views are also an important provider of cultural ecosystem service (Martínez Pastur et al. 2016; Yoshimura and Hiura 2017). However, this type of service could, to some degree, also be provided by an area with artificial components and non-biological materials. Conversely, artificial components and non-biological materials may not have the appeal of species diversity, as reflected by people's preference in close-up views. Natural or semi-natural habitat diversity is compatible with close-up and scenic types of cultural services. The most important point is phenology, which is an ecological phenomenon providing an additional ecosystem service. A previous study has also suggested that 
natural and semi-natural mosaic landscapes could provide more services than an artificial landscape (Felipe-lucia and Comín 2015). This study revealed the importance of not only habitat diversity but also ecological phenomena in providing ecosystem services.

Biologists tend to concentrate on species diversity, with a particular emphasis on threatened species as an index of habitat value (Balvanera et al. 2014). In this context, habitats containing threatened species are considered to be of higher value than those without (Camaclang et al. 2014). In contrast, Dallimer et al. (2012) pointed out that the discrepancy between reality and perception of biodiversity was influenced by the biodiversity-identification skills of people and could produce a gap between biodiversity conservation and human well-being (Dallimer et al. 2012). In this study, we used photos taken by cognitively-impaired students who were unlikely to have any biases, such as focusing on species that have been assigned as threatened. Interestingly, people in our study took a higher proportion of close-up photos in areas containing threatened plants during spring-autumn, but did not photograph the threatened species themselves. In addition, objects were not biased towards highly visible species, such as those with large colourful flowers (Suppl. material 2: Fig. S2). This may indicate that the concrete preferences of biologists and/or society and those of our participants were different; however, the habitats that contained the threatened species did seem to appeal to the study participants even if their preferences were focused elsewhere. Although we were unable to identify any specific reason for this behaviour, future studies should test whether and why people have a greater preference for species in unique habitats, even if the species are not threatened.

\section{Conclusions}

The non-material value of ecosystems, including cultural services, should be evaluated as part of the total ecosystem value for humans (Chan et al. 2012a; Doi et al. 2013; Van Berkel and Verburg 2014). Thus, surveys that incorporate social and ecological perspectives provide novel evidence of the relationships between ecosystems and human society (Chan et al. 2012a; Doi et al. 2013; Garrido et al. 2017). However, cultural services do not represent purely ecological phenomena, but are rather the outcome of complex and dynamic relationships between ecosystems and humans (Fagerholm et al. 2012; Garrido et al. 2017). In this study, we used people preference as an index of cultural ecosystem service and found that the habitat diversity of a semi-natural environment with species diversity provides a cultural service that appears to fulfil diverse subjective interests. Cultural ecosystem services are co-generated with humans and the environment (Casado-Arzuaga et al. 2014); thus, interaction between people preference and habitat type is according to that idea. Additionally, we found one link between ecological phenomena and cultural services, namely, contact with the socioecological system. This contact could contribute to maintaining human-biodiversity relationships (Kasada et al. 2017). Based on these results, the habitat conservation of semi-natural environments that can be utilised by humans, such as natural parks, could synergise with both biodiversity conservation and general human well-being. 


\section{Acknowledgements}

We thank Mr. A. Ono and Ms. Y. Kuriyama for their assistance with several activities. We also thank the students and teachers participating in the study. Two anonymous reviewers gave us several useful comments. This study was supported by the Environment Research and Technology Development Fund (4-1504, 4-1705) of the Ministry of the Environment, Japan.

\section{References}

Balvanera P, Siddique I, Dee L, Paquette A, Isbell F, Gonzalez A, Byrnes J, O'Connor MI, Hungate BA, Griffin JN (2014) Linking biodiversity and ecosystem services: Current uncertainties and the necessary next steps. Bioscience 64(1): 49-57. https://doi.org/10.1093/ biosci/bit003

Boerema A, Rebelo AJ, Bodi MB, Esler KJ, Meire P (2017) Are ecosystem services adequately quantified? Journal of Applied Ecology 54(2): 358-370. https://doi.org/10.1111/13652664.12696

Cadotte MW (2013) Experimental evidence that evolutionarily diverse assemblages result in higher productivity. Proceedings of the National Academy of Sciences of the United States of America 110(22): 8996-9000. https://doi.org/10.1073/pnas.1301685110

Camaclang AE, Maron M, Martin TG, Possingham HP (2014) Current practices in the identification of critical habitat for threatened species. Conservation Biology 29(2): 482-492. https://doi.org/10.1111/cobi.12428

Cardinale BJ, Duffy JE, Gonzalez A, et al. (2012) Corrigendum: Biodiversity loss and its impact on humanity. Nature 489: 326-326. https://doi.org/10.1038/nature11373

Casado-Arzuaga I, Onaindia M, Madariaga I, Verburg PH (2014) Mapping recreation and aesthetic value of ecosystems in the Bilbao Metropolitan Greenbelt (northern Spain) to support landscape planning. Landscape Ecology 29(8): 1393-1405. https://doi.org/10.1007/ s10980-013-9945-2

Castro AJ, Verburg PH, Martín-López B, Garcia-Llorente M, Cabello J, Vaughn CC, López E (2014) Ecosystem service trade-offs from supply to social demand: A landscape-scale spatial analysis. Landscape and Urban Planning 132: 102-110. https://doi.org/10.1016/j. landurbplan.2014.08.009

Chan KMA, Goldstein J, Satterfield T, et al. (2011) Cultural services and non-use values. Theory Pract Ecosyst Serv Valuat Conserv, 206-228. https://doi.org/10.1093/acprof:o so/9780199588992.003.0012

Chan KMA, Guerry AD, Balvanera P, Klain S, Satterfield T, Basurto X, Bostrom A, Chuenpagdee R, Gould R, Halpern BS, Hannahs N, Levine J, Norton B, Ruckelshaus M, Russell R, Tam J, Woodside U (2012a) Where are Cultural and Social in Ecosystem Services? A Framework for Constructive Engagement. Bioscience 62(8): 744-756. https://doi. org/10.1525/bio.2012.62.8.7 
Chan KMA, Satterfield T, Goldstein J (2012b) Rethinking ecosystem services to better address and navigate cultural values. Ecological Economics 74: 8-18. https://doi.org/10.1016/j. ecolecon.2011.11.011

Cumming GS, Maciejewski K (2017) Reconciling community ecology and ecosystem services: Cultural services and benefits from birds in South African National Parks. Ecosystem Services 28: 219-227. https://doi.org/10.1016/j.ecoser.2017.02.018

Dallimer M, Irvine KN, Skinner AMJ, Davies ZG, Rouquette JR, Maltby LL, Warren PH, Armsworth PR, Gaston KJ (2012) Biodiversity and the Feel-Good Factor: Understanding Associations between Self-Reported Human Well-being and Species Richness. Bioscience 62(1): 47-55. https://doi.org/10.1525/bio.2012.62.1.9

de Groot RS, Alkemade R, Braat L, Hein L, Willemen L (2010) Challenges in integrating the concept of ecosystem services and values in landscape planning, management and decision making. Ecological Complexity 7(3): 260-272. https://doi.org/10.1016/j.ecocom.2009.10.006

Doi H, Katano I, Negishi JN, Sanada S, Kayaba Y (2013) Effects of biodiversity, habitat structure, and water quality on recreational use of rivers. Ecosphere 4(8): art102. https://doi. org/10.1890/ES12-00305.1

Fagerholm N, Käyhkö N, Ndumbaro F, Khamis M (2012) Community stakeholders' knowledge in landscape assessments - Mapping indicators for landscape services. Ecological Indicators 18: 421-433. https://doi.org/10.1016/j.ecolind.2011.12.004

Felipe-lucia MR, Comín FA (2015) Land Use Policy Ecosystem services - biodiversity relationships depend on land use type in floodplain agroecosystems. Land Use Policy 46: 201-210. https://doi.org/10.1016/j.landusepol.2015.02.003

Garrido P, Elbakidze M, Angelstam P, Plieninger T, Pulido F, Moreno G (2017) Stakeholder perspectives of wood-pasture ecosystem services: A case study from Iberian dehesas. Land Use Policy 60: 324-333. https://doi.org/10.1016/j.landusepol.2016.10.022

Gomes VHF, IJff SD, Raes N, Amaral IL, Salomão RP, de Souza Coelho L, de Almeida Matos FD, Castilho CV, de Andrade Lima Filho D, López DC, Guevara JE, Magnusson WE, Phillips OL, Wittmann F, de Jesus Veiga Carim M, Martins MP, Irume MV, Sabatier D, Molino J-F, Bánki OS, da Silva Guimarães JR, Pitman NCA, Piedade MTF, Mendoza AM, Luize BG, Venticinque EM, de Leão Novo EMM, Vargas PN, Silva TSF, Manzatto AG, Terborgh J, Reis NFC, Montero JC, Casula KR, Marimon BS, Marimon B-H, Coronado ENH, Feldpausch TR, Duque A, Zartman CE, Arboleda NC, Killeen TJ, Mostacedo B, Vasquez R, Schöngart J, Assis RL, Medeiros MB, Simon MF, Andrade A, Laurance WF, Camargo JL, Demarchi LO, Laurance SGW, de Sousa Farias E, Nascimento HEM, Revilla JDC, Quaresma A, Costa FRC, Vieira ICG, Cintra BBL, Castellanos H, Brienen R, Stevenson PR, Feitosa Y, Duivenvoorden JF, Aymard CGA, Mogollón HF, Targhetta N, Comiskey JA, Vicentini A, Lopes A, Damasco G, Dávila N, García-Villacorta R, Levis C, Schietti J, Souza P, Emilio T, Alonso A, Neill D, Dallmeier F, Ferreira LV, Araujo-Murakami A, Praia D, do Amaral DD, Carvalho FA, de Souza FC, Feeley K, Arroyo L, Pansonato MP, Gribel R, Villa B, Licona JC, Fine PVA, Cerón C, Baraloto C, Jimenez EM, Stropp J, Engel J, Silveira M, Mora MCP, Petronelli P, Maas P, Thomas-Caesar R, Henkel TW, Daly D, Paredes MR, Baker TR, Fuentes A, Peres CA, Chave J, Pena JLM, Dexter KG, Silman 
MR, Jørgensen PM, Pennington T, Di Fiore A, Valverde FC, Phillips JF, Rivas-Torres G, von Hildebrand P, van Andel TR, Ruschel AR, Prieto A, Rudas A, Hoffman B, Vela CIA, Barbosa EM, Zent EL, Gonzales GPG, Doza HPD, de Andrade Miranda IP, Guillaumet J-L, Pinto LFM, de Matos Bonates LC, Silva N, Gómez RZ, Zent S, Gonzales T, Vos VA, Malhi Y, Oliveira AA, Cano A, Albuquerque BW, Vriesendorp C, Correa DF, Torre EV, van der Heijden G, Ramirez-Angulo H, Ramos JF, Young KR, Rocha M, Nascimento MT, Medina MNU, Tirado M, Wang O, Sierra R, Torres-Lezama A, Mendoza C, Ferreira C, Baider C, Villarroel D, Balslev H, Mesones I, Giraldo LEU, Casas LF, Reategui MAA, Linares-Palomino R, Zagt R, Cárdenas S, Farfan-Rios W, Sampaio AF, Pauletto D, Sandoval EHV, Arevalo FR, Huamantupa-Chuquimaco I, Garcia-Cabrera K, Hernandez L, Gamarra LV, Alexiades MN, Pansini S, Cuenca WP, Milliken W, Ricardo J, Lopez-Gonzalez G, Pos E, ter Steege H (2018) Species Distribution Modelling: Contrasting presence-only models with plot abundance data. Scientific Reports 8(1): 1003. https://doi.org/10.1038/ s41598-017-18927-1

Hernández-Morcillo M, Plieninger T, Bieling C (2013) An empirical review of cultural ecosystem service indicators. Ecological Indicators 29: 434-444. https://doi.org/10.1016/j. ecolind.2013.01.013

Kasada M, Matsuba M, Miyashita T (2017) Human interest meets biodiversity hotspots: A new systematic approach for urban ecosystem conservation. PLoS One 12(2): e0172670. https://doi.org/10.1371/journal.pone.0172670

Mace GM, Norris K, Fitter AH (2012) Biodiversity and ecosystem services: A multilayered relationship. Trends in Ecology \& Evolution 27(1): 19-25. https://doi.org/10.1016/j. tree.2011.08.006

Millennium Ecosystem Assessment (2005) Ecosystems and human well-being. Island Press Washington, DC.

Martin-López B, Iniesta-Arandia I, Garcia-Llorente M, Palomo I, Casado-Arzuaga I, Amo DGD, Gómez-Baggethun E, Oteros-Rozas E, Palacios-Agundez I, Willaarts B, González JA, Santos-Martín F, Onaindia M, López-Santiago C, Montes C (2012) Uncovering ecosystem service bundles through social preferences. PLoS One 7(6): e38970. https://doi. org/10.1371/journal.pone.0038970

Martínez Pastur G, Peri PL, Lencinas MV, García-Llorente M, Martín-López B (2016) Spatial patterns of cultural ecosystem services provision in Southern Patagonia. Landscape Ecology 31(2): 383-399. https://doi.org/10.1007/s10980-015-0254-9

Marull J, Tello E, Fullana N, Murray I, Jover G, Font C, Coll F, Domene E, Leoni V, Decolli T (2015) Long-term bio-cultural heritage: Exploring the intermediate disturbance hypothesis in agro-ecological landscapes (Mallorca, ca. 1850-2012). Biodiversity and Conservation 24(13): 3217-3251. https://doi.org/10.1007/s10531-015-0955-z

Mori AS (2017) Biodiversity and ecosystem services in forests: Management and restoration founded on ecological theory. Journal of Applied Ecology 54: 7-11. https://doi. org/10.1111/1365-2664.12854

Osawa T, Mitsuhashi H, Niwa H, Ushimaru A (2010a) Enhanced diversity at network nodes: River confluences increase vegetation-patch diversity. The Open Ecology Journal 3(1): 48-58. https://doi.org/10.2174/1874213001003010048 
Osawa T, Mitsuhashi H, Niwa H, Ushimaru A (2010b) Differences in distribution patterns around river confluences among hydrophilic vegetation groups. Ecological Research 25(6): 1161-1169. https://doi.org/10.1007/s11284-010-0741-z

Ozono A, Kawashima I, Futahashi R (2012) Dragonflies of Japan. Bun-Ichi syuppan, Tokyo. [in Japanese]

Plieninger T, Dijks S, Oteros-Rozas E, Bieling C (2013) Assessing, mapping, and quantifying cultural ecosystem services at community level. Land Use Policy 33: 118-129. https://doi. org/10.1016/j.landusepol.2012.12.013

Schwarz N, Moretti M, Bugalho MN, Davies ZG, Haase D, Hack J, Hof A, Melero Y, Pett TJ, Knapp S (2017) Understanding biodiversity-ecosystem service relationships in urban areas: A comprehensive literature review. Ecosystem Services 27: 161-171. https://doi. org/10.1016/j.ecoser.2017.08.014

Sherrouse BC, Clement JM, Semmens DJ (2011) A GIS application for assessing, mapping, and quantifying the social values of ecosystem services. Applied Geography (Sevenoaks, England) 31(2): 748-760. https://doi.org/10.1016/j.apgeog.2010.08.002

Shizuoka Prefecture, Shizuoka City Council on Asabata Yusuichi (2008) Restoration plan for Asabata Yusuichi. [in Japanese]

Takagawa S, Ueta M, Amano T, et al. (2011) JAVIAN Database: A species-level database of life history, ecology and morphology of bird species in Japan [JAVIAN Database]. Bird Res 7: R9-R12.

Thompson PL, Isbell F, Loreau M, O'Connor MI, Gonzalez A (2018) The strength of the biodiversity - ecosystem function relationship depends on spatial scale. Proceedings. Biological Sciences 285(1880): 20180038. https://doi.org/10.1098/rspb.2018.0038

Tilman D, Reich PB, Knops JMH (2006) Biodiversity and ecosystem stability in a decade-long grassland experiment. Nature 441(7093): 629-632. https://doi.org/10.1038/nature04742

Tscharntke T, Klein AM, Kruess A, Steffan-Dewenter I, Thies C (2005) Landscape perspectives on agricultural intensification and biodiversity - Ecosystem service management. Ecology Letters 8(8): 857-874. https://doi.org/10.1111/j.1461-0248.2005.00782.x

Van Berkel DB, Verburg PH (2014) Spatial quantification and valuation of cultural ecosystem services in an agricultural landscape. Ecological Indicators 37: 163-174. https://doi. org/10.1016/j.ecolind.2012.06.025

Yoshimura N, Hiura T (2017) Demand and supply of cultural ecosystem services: Use of geotagged photos to map the aesthetic value of landscapes in Hokkaido. Ecosystem Services 24: 68-78. https://doi.org/10.1016/j.ecoser.2017.02.009

Yoshioka A, Fukasawa K, Mishima Y, Sasaki K, Kadoya T (2017) Ecological dissimilarity among land-use/land-cover types improves a heterogeneity index for predicting biodiversity in agricultural landscapes. Ambio 46(8): 894-906. https://doi.org/10.1007/s13280017-0925-7 


\section{Supplementary material I}

\section{Figure S1. Typical pictures in each composition}

Authors: Takeshi Osawa, Yusuke Ueno, Takaaki Nishida, Jun Nishihiro

Copyright notice: This dataset is made available under the Open Database License (http://opendatacommons.org/licenses/odbl/1.0/). The Open Database License $(\mathrm{ODbL})$ is a license agreement intended to allow users to freely share, modify, and use this Dataset while maintaining this same freedom for others, provided that the original source and author(s) are credited.

Link: https://doi.org/10.3897/natureconservation.38.36166.suppl1

\section{Supplementary material 2}

\section{Figure S2. Pictures took in mesh which have any threaten species}

Authors: Takeshi Osawa, Yusuke Ueno, Takaaki Nishida, Jun Nishihiro

Explanation note: All objects were not the threaten species itself.

Copyright notice: This dataset is made available under the Open Database License (http://opendatacommons.org/licenses/odbl/1.0/). The Open Database License $(\mathrm{ODbL})$ is a license agreement intended to allow users to freely share, modify, and use this Dataset while maintaining this same freedom for others, provided that the original source and author(s) are credited.

Link: https://doi.org/10.3897/natureconservation.38.36166.suppl2

\section{Supplementary material 3}

\section{Tables S1-S6}

Authors: Takeshi Osawa, Yusuke Ueno, Takaaki Nishida, Jun Nishihiro Explanation note: Table S1. All plants and main habitats in the study area. Table S2. All birds and main habitats in the study area. Table S3. All butterflies and main habitats in the study area. Table S4. All dragonflies and main habitats in the study area. Table S5. List of threatened plants in the study area. Table S6. Picture objects list which took in area with threatened species from spring to autumn.

Copyright notice: This dataset is made available under the Open Database License (http://opendatacommons.org/licenses/odbl/1.0/). The Open Database License $(\mathrm{ODbL})$ is a license agreement intended to allow users to freely share, modify, and use this Dataset while maintaining this same freedom for others, provided that the original source and author(s) are credited.

Link: https://doi.org/10.3897/natureconservation.38.36166.suppl3 